This item was submitted to Loughborough's Research Repository by the author.

Items in Figshare are protected by copyright, with all rights reserved, unless otherwise indicated.

\title{
Measured winter and spring-time indoor temperatures in UK homes over the period 1969-2010: A review and synthesis
}

PLEASE CITE THE PUBLISHED VERSION

http://dx.doi.org/10.1016/j.enpol.2013.07.062

PUBLISHER

(C) Elsevier Ltd.

VERSION

AM (Accepted Manuscript)

LICENCE

CC BY-NC-ND 4.0

\section{REPOSITORY RECORD}

Vadodaria, Keyur, Dennis L. Loveday, and Victoria Haines. 2019. "Measured Winter and Spring-time Indoor Temperatures in UK Homes over the Period 1969-2010: A Review and Synthesis". figshare.

https://hdl.handle.net/2134/14603. 
This item was submitted to Loughborough's Institutional Repository (https://dspace.lboro.ac.uk/) by the author and is made available under the following Creative Commons Licence conditions.

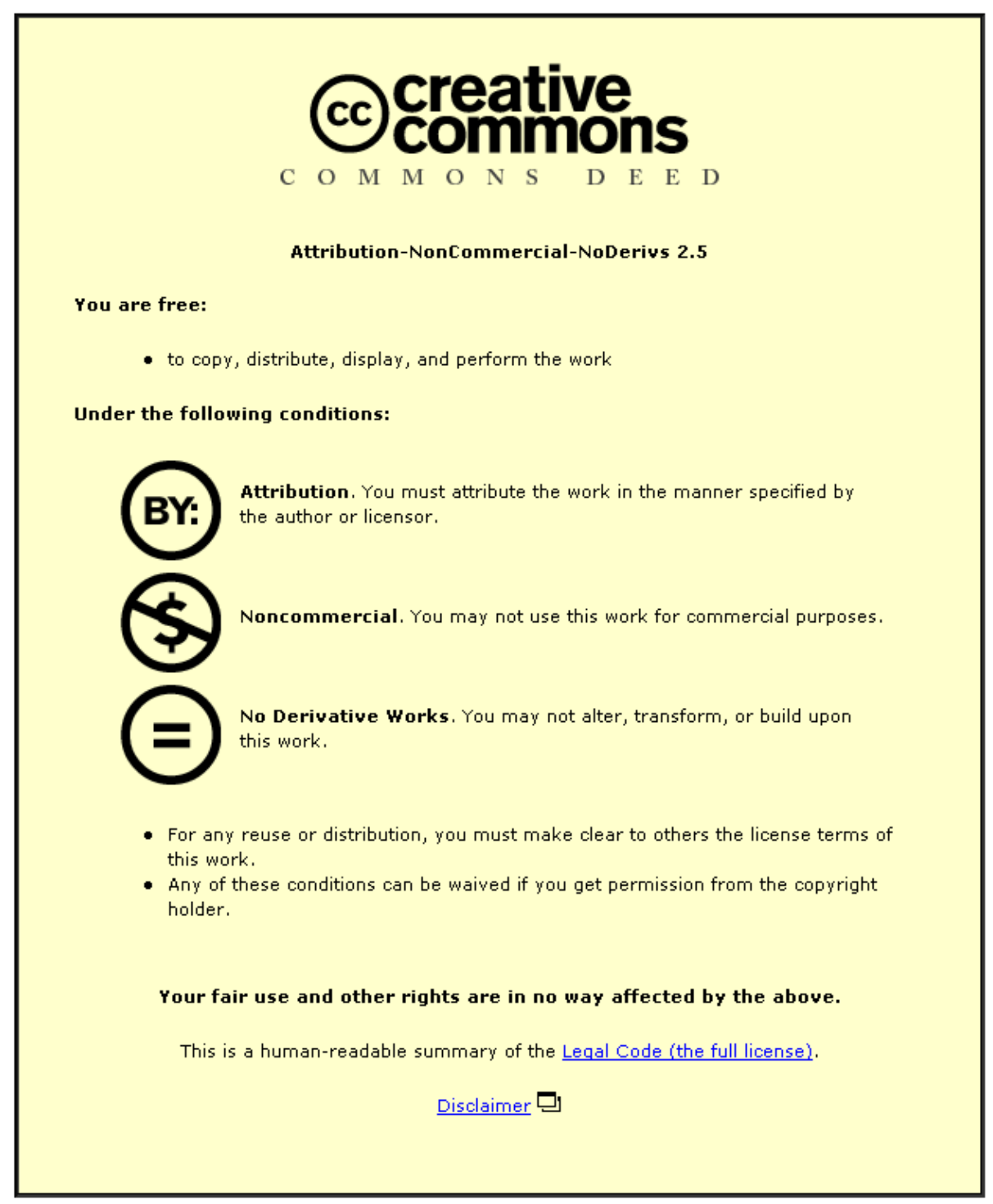

For the full text of this licence, please go to: http://creativecommons.org/licenses/by-nc-nd/2.5/ 


\title{
Measured winter and spring-time indoor temperatures in UK
}

\section{homes over the period 1969 to 2010: a review and synthesis}

\author{
K. Vadodaria ${ }^{a,}{ }^{*}$, D. L. Loveday ${ }^{a}$ and V. Haines ${ }^{b}$ \\ ${ }^{a}$ School of Civil and Building Engineering, Loughborough University, Loughborough LE11 3TU, UK \\ b Loughborough Design School, Loughborough University, Loughborough LE11 3TU, UK \\ * Corresponding author: Keyur Vadodaria \\ Tel.: +44 01509222897 \\ E-mail address: k.vadodaria@lboro.ac.uk
}

Abstract

This paper presents a review and synthesis of average winter and spring-time indoor temperatures in UK homes measured over the period 1969 to 2010. Analysis of measured temperatures in a sample of solid wall dwellings in the UK, conducted as part of the CALEBRE research project, is included. The review suggests that, for periods when occupation was likely, there has been little or no increase in winter and spring-time average living room temperatures over the last 40 years, with average recorded living room temperatures having been historically lower than the WHO-recommended value of $21^{\circ} \mathrm{C}$. Correspondingly, for periods of likely occupation, average bedroom temperatures appear to have increased. Compared with non-domestic buildings, there have been fewer investigations of domestic thermal comfort, either in the UK or elsewhere, and hence the paper also calls for further detailed investigations of domestic indoor temperatures during occupied hours together with thermal comfort evaluations in order to better understand domestic thermal environments. Based on suggestions from the limited range of studies available to date, living room temperatures may need to be maintained within the range 20- 
$22{ }^{\circ} \mathrm{C}$ for thermal satisfaction, though this requires confirmation through further research. The study also emphasises that improving the energy efficiency of homes should be the primary means to effect any increases in indoor temperatures that are deemed essential. Considerations for future policy are discussed.

\section{Keywords}

UK solid wall dwellings

Indoor temperatures

Domestic Thermal comfort

\section{Introduction}

Within the UK, energy used in homes accounts for more than $25 \%$ of total national energy consumption. Up to two thirds of the energy used in homes is for the purposes of space and water heating, with the attainment of occupant thermal comfort therefore having a direct bearing on energy demand. The UK Government is embarking upon a large scale program of refurbishment for its housing stock, financially supported by the 'Green Deal', with the aim of improving the energy efficiency of existing homes through improvement in space and water heating systems and reductions in whole house heat loss. However, there is a risk that much of the anticipated energy savings may not be realized in practice as people may choose to maintain their homes at temperatures higher than those before refurbishment. Studies have shown that actual savings from the energy efficient retrofitting of existing houses have amounted to less than half of the predicted savings for a variety of reasons that include quality and detailing of the refurbishment process as well as the 'takeback’ process - the latter initiated due to improvements in thermal comfort (Hong et al. 2006). The ‘take-back’ (a result of improved thermal comfort and consequently reduced 
clothing level) was also observed in another study where an increase of whole house neutral temperature from $18.9^{\circ} \mathrm{C}$ to $19.1^{\circ} \mathrm{C}$ was recorded after the installation of energy efficiency measures (Hong et al. 2009). Therefore, an in-depth understanding of indoor thermal conditions and people's domestic thermal comfort is required so that energy efficiency upgrades are delivered, and anticipated energy savings are achieved, whilst also fulfilling people's thermal comfort needs. Currently there is limited knowledge on domestic thermal comfort in the UK, and a number of questions arise - for example, at what temperatures are people actually living in their homes? Are people thermally satisfied with the temperatures in their homes? Are people living in temperatures close to the World Health Organisation (WHO) - recommended values of $21^{\circ} \mathrm{C}$ in living rooms and $18^{\circ} \mathrm{C}$ in bedrooms? There appears to be a generally-held belief that UK domestic indoor temperatures have been increasing over the last few decades, but is this actually the case? This paper provides some answers, clarifications and insights that help towards addressing these questions. This is achieved by conducting a historical review and synthesis of measured data on temperatures in UK homes since 1969, together with an analysis of the temperature data that were recorded in solid-walled homes in the East Midlands area as part of the CALEBRE ${ }^{1}$ research project.

\subsection{A review of measured UK domestic temperatures}

A review of indoor temperatures recorded in surveys of UK homes from 1969 is given in this section and is largely focused on heating season (winter and spring) temperatures. An increased awareness of the health risks to the elderly as a result of living in low indoor temperatures in cold environments led to studies of indoor temperatures in homes during the 1960s and 1970s. A survey conducted in February1969 of 144 homes (a mix of modern flats and substandard homes) occupied by elderly people found that living room and 
bedroom temperatures were in the range of $3-14^{\circ} \mathrm{C}$ in substandard houses while in modern flats they were in the range of $9-17^{\circ} \mathrm{C}$ (Collins, 1986). One of the first large scale surveys of indoor temperatures was carried out in the winter of 1972 and covered a sample of 1020 elderly people (aged 65 and over) living in 100 constituencies across Great Britain, including the London Borough of Camden (Fox et al. 1973). Average living room temperatures of $16.2^{\circ} \mathrm{C}$ and $18.2^{\circ} \mathrm{C}$ were recorded in homes across the UK and in Camden, respectively. The study found that in the majority of the cases (75\%), living room temperatures were below $18.3^{\circ} \mathrm{C}$. This was close to the minimum level of $18^{\circ} \mathrm{C}$ that had been recommended by the Parker Morris report of 1961 (Ministry of Housing and Local Government, 1961) as a heating standard for living areas (but not bedrooms) when the external temperature was $-1^{\circ} \mathrm{C}$. The purpose of the Parker Morris report of 1961 had been to consider standards of design and equipment for family dwellings and other forms of residential accommodation. The report also identified that better heating was a key design factor, with homes at the time being recognised as too cold for daytime and evening use, except in summer. This came alongside an increasing demand for higher domestic comfort levels to match expectations acquired from conditions in offices and factories.

A repeat study of 47 elderly residents in the London Borough of Camden was subsequently conducted in 1975-6. The study recorded a mean living room temperature of $18.4^{\circ} \mathrm{C}$ during afternoons (Collins et al. 1977).

To investigate at what temperatures people were living in their homes, a large scale survey was carried out by The Building Research Establishment in 1978 (Hunt \& Gidman, 1982). The survey took spot measurements of temperatures in each room of the randomly selected 1000 dwellings. The dwellings were a mix of owner occupied and local authority rented properties and were located in 50 towns across England, Scotland and Wales. 
Measurements were taken during mornings, afternoons and evenings, and on weekdays as well as weekends. An average living room temperature of $18.3^{\circ} \mathrm{C}$, and an average bedroom temperature of $14.6^{\circ} \mathrm{C}$, was recorded across the sample.

In order to understand the impact of insulation levels and occupant preferences on internal temperatures, a field study of 33 houses (almost equal numbers of un-insulated and retrofitinsulated homes) and 7 newly-built, well-insulated homes was conducted in 1977/78 by the Watson House Research Centre of the British Gas Corporation (Nevrala \& Pimbert, 1981). Temperatures in living rooms and bedrooms were continuously recorded throughout the monitoring period. The survey recorded an average internal temperature of $19.8^{\circ} \mathrm{C}$ in uninsulated homes, $20.3^{\circ} \mathrm{C}$ in retrofit-insulated homes and $21.6^{\circ} \mathrm{C}$ in new-built insulated homes during evenings, with $90 \%$ of the respondents voting these temperatures as satisfactory. Four participants of this study had also taken part in another study of subjective responses to temperatures in office environments. Comparison of both studies highlighted that average evening living room temperatures in these participants' homes (which were reported as satisfactory) were $3^{\circ} \mathrm{C}$ lower than the long term preferred temperature at the office. The study suggested that the increased tolerance toward lower temperatures at home could be as a result of people having to pay for their domestic fuel themselves (as opposed to their employer paying the fuel bill).

A survey of internal temperatures in new homes was conducted by Oseland in winter and summer of 1991/92 with the aim of investigating differences between reported and predicted neutral temperatures in homes as well as seasonal differences in neutral temperatures (Oseland, 1994). An average living room temperature of $19.3^{\circ} \mathrm{C}$ was recorded in winter in 515 homes, whilst in summer an average living room temperature of $21.7^{\circ} \mathrm{C}$ 
was recorded in 293 homes. The study observed that the neutral temperature was lower $\left(5^{\circ} \mathrm{C}\right.$ lower in winter and $3^{\circ} \mathrm{C}$ lower in summer) than those predicted using the Standard ISO 7730 (BSI, 2005). The study also observed that the participants rated themselves warmer in winter than in summer, even though living room temperatures were lower during the winter period.

The comprehensive English House Condition Survey (EHCS) in 1986 recorded temperatures of $18^{\circ} \mathrm{C}$ in the living rooms of 2177 homes across the UK (DOE, 1995). The 1991 EHCS recorded an average living room temperature of $18.6^{\circ} \mathrm{C}$ in a total of 25,000 centrally heated and non-centrally heated homes. Spot measurements of temperatures were taken during interviews (DOE, 1996), thus implying that the recorded temperatures were representative of values that prevailed during occupancy. The 1996 EHCS recorded average living room temperatures of $18.1^{\circ} \mathrm{C}$ (DETR, 2000). Temperature measurements were discontinued after the EHCS of 1996 and currently there are no comprehensive data available from the EHCS on internal temperatures in UK dwellings for the period after 1996.

A handful of surveys on indoor air temperature in dwellings have been carried out since 1996, but they were conducted primarily in fuel poor and low income households. The Warm Front Study Group recorded winter indoor temperatures in low income households in the UK and observed a median standardized daytime living room temperature of $19.1^{\circ} \mathrm{C}$ and a median standardized night time bedroom temperature of $17.1^{\circ} \mathrm{C}$ (Oreszczyn et al. 2006). Extrapolating detailed temperature data from a subset of 1600 dwellings, the study observed that dwellings that received both heating and insulation measures through the Warm Front scheme had daytime living room temperatures $1.6^{\circ} \mathrm{C}$ higher and night time 
bedroom temperatures $2.8^{\circ} \mathrm{C}$ higher than pre-intervention dwellings. Furthermore, actual energy savings were lower than the theoretically-predicted energy savings, suggesting a 'takeback' effect. 'Takeback' is a comfort-related phenomenon, and is defined as ' $a$ shortfall in actual energy savings in practice as a result of an increase in the average indoor temperature of the houses, following an energy efficiency upgrade, due to the physical processes involved and because the occupants deliberately take back some of the potential energy savings as improved comfort' (Milne \& Boardman, 2000).

The CaRB project conducted a follow-up study of 15 'low-energy’ dwellings in Milton Keynes, UK (Summerfield et al. 2007). Temperature was continuously monitored during 2005-2006 and was compared with monitoring carried out in 1989-1991 to determine changes in internal temperatures and energy use. Results indicated no significant change in average internal temperatures over the 15 years under standardised daily outdoor conditions $\left(5^{\circ} \mathrm{C}\right)$. An average temperature of $20.1^{\circ} \mathrm{C}\left(0.2^{\circ} \mathrm{C}\right.$ higher than 1990$)$ was recorded in living rooms, with $19.3^{\circ} \mathrm{C}\left(0.4^{\circ} \mathrm{C}\right.$ lower than 1990) being recorded in main bedrooms. The study did, however, find an increase of up to $20-30 \%$ in energy consumption in these houses. The study noted that energy consumption may not necessarily stabilise and may even increase even if internal temperatures stabilise or decline in future.

Yohanis and Mondol conducted a survey of the internal temperatures of 25 households in Northern Ireland in 2007 (Yohanis \& Mondol, 2010). The survey, conducted from February 2004 to January 2005, recorded daily average temperatures of $15.6^{\circ} \mathrm{C}$ to $21.7^{\circ} \mathrm{C}$ in living rooms, and $16.1^{\circ} \mathrm{C}$ to $20.5^{\circ} \mathrm{C}$ in bedrooms in the winter. During summer, the survey recorded daily average temperatures of $20.1^{\circ} \mathrm{C}$ to $22.2^{\circ} \mathrm{C}$ in living rooms, and daily 
average temperatures of $20^{\circ} \mathrm{C}$ to $22.2^{\circ} \mathrm{C}$ in bedrooms. Overall, the survey recorded an average temperature of $20.5^{\circ} \mathrm{C}$ in living rooms and $19.9^{\circ} \mathrm{C}$ in bedrooms.

The 'Challenge 100’ project carried out by E.ON, the energy utility company, monitored living room and bedroom temperatures in homes located in the Birmingham (Midlands) area of the UK during 2010 (E.ON, 2010). These homes were occupied by households who were identified as being 'fuel poor'. At the time of the study, the prevailing definition was that a household is said to be in fuel poverty if it needs to spend more than $10 \%$ of its income on fuel to maintain a satisfactory heating regime (usually $21^{\circ} \mathrm{C}$ for the main living area, and $18^{\circ} \mathrm{C}$ for other occupied rooms) (DECC, 2011). The aim of the Challenge 100 project was to eradicate fuel poverty for 100 families, in 100 homes, in 100 days. Therefore, energy efficiency upgrades were carried out for these houses, and temperatures were monitored after the refurbishment. An average temperature of $19.2^{\circ} \mathrm{C}$ in living rooms and $19.3^{\circ} \mathrm{C}$ in bedrooms was recorded. The review of measured UK domestic temperatures presented above, together with further recent data to be presented in the next section, is discussed later in section 4 of this paper.

\subsection{Current temperatures in UK homes- the CALEBRE sample}

\subsection{Background to the CALEBRE study}

According to the English House Conditions Survey 2006, solid-walled dwellings (6.6 million) constitute approximately $31 \%$ of the total UK housing stock. With a view to understanding at what temperatures people were living in their solid-walled homes, the CALEBRE research project undertook monitoring of living room and bedroom temperatures in 20 solid-walled, owner-occupied homes (housing a total of 66 residents) in and around the town of Loughborough (East Midlands, UK). The monitoring was carried 
out from February 2010 to May 2010. The EHCS database was used to understand the national profile of the solid wall housing stock and to identify a sample of houses for investigation that would provide a representative cross-section of different domestic situations. Participants were selected using a purposive sampling approach such that they not only lived in a wide range of house types, but also represented a variety of family structures, incomes and social statuses. Comparison of the CALEBRE sample with the EHCS data is given in Table $0-1$.

Table 0-1: Comparison of the 'CALEBRE' sample with the EHCS national profile of solid wall dwellings.

\begin{tabular}{|c|c|c|}
\hline Criterion & EHCS & 'CALEBRE’ sample \\
\hline Dwelling Type & $\begin{array}{l}70 \% \text { of the solid wall housing stock consists } \\
\text { of end terrace, mid terrace, semi-detached } \\
\text { and detached property types }\end{array}$ & $\begin{array}{l}\text { Equal numbers ( } 5 \text { of each) of end, mid, semi and } \\
\text { detached properties }\end{array}$ \\
\hline Dwelling Size & $\begin{array}{l}85 \% \text { of solid wall properties have an area of } \\
\text { more than } 50 \text { sqm, the remaining } 15 \% \text { (being } \\
\text { less than } 50 \text { sqm) comprising } 1-2 \text { bedroom } \\
\text { properties. }\end{array}$ & $\begin{array}{l}\text { All CALEBRE properties had an area of more } \\
\text { than 50sqm }\end{array}$ \\
\hline $\begin{array}{l}\text { Regional Locations } \\
\text { (Government office } \\
\text { regions) }\end{array}$ & $\begin{array}{l}30 \% \text { of the total solid wall housing stock is } \\
\text { in London, while less than } 3 \% \text { are in the } \\
\text { north east, the rest being located evenly in } \\
\text { other regions }\end{array}$ & All properties located in East Midlands \\
\hline $\begin{array}{l}\text { Regional Location } \\
\text { (urban /rural) }\end{array}$ & $\begin{array}{l}75 \% \text { of the total solid wall housing stock is } \\
\text { located in urban centres (not city centres) } \\
\text { and suburban residential regions }\end{array}$ & $\begin{array}{l}75 \% \text { of CALEBRE properties ( } \mathrm{n}=15 \text { ) in urban } \\
\text { centres and suburban residential regions. } \\
\text { Remaining properties: } 10 \% \text { village centre, } 5 \% \\
\text { city centre, } 5 \% \text { rural residential, } 5 \% \text { rural }\end{array}$ \\
\hline Type of Tenure & $\begin{array}{l}80 \% \text { of the total solid wall housing stock is } \\
\text { owner occupied and privately rented } \\
\text { occupied }\end{array}$ & All owner occupied \\
\hline Type of Fuel Used & $\begin{array}{l}85 \% \text { of solid wall dwellings use gas for } \\
\text { heating. }\end{array}$ & All gas central heating \\
\hline $\begin{array}{l}\text { Household } \\
\text { Composition }\end{array}$ & $\begin{array}{l}\text { Solid wall properties have an even mix of } \\
\text { household composition that includes couples } \\
\text { less than } 60 \text { years of age with and without } \\
\text { dependent children, couples above the age of } \\
60 \text { years with no dependent children, multi } \\
\text { person households and lone parents. }\end{array}$ & $\begin{array}{l}55 \% \text { of CALEBRE households were couples } \\
\text { aged less than } 60 \text { years with dependent children; } \\
15 \% \text { multi person households; } 10 \% \text { couples } \\
\text { under } 60 \text { years with no dependent children; } 10 \% \\
\text { lone person over } 60 \text { years; } 5 \% \text { couples less than } \\
60 \text { years without dependent children; } 5 \% \text { lone } \\
\text { person less than } 60 \text { years }\end{array}$ \\
\hline Household Size & $\begin{array}{l}90 \% \text { of solid wall properties have a } \\
\text { household size in the range of } 1 \text { to } 4 \\
\text { occupants with less than } 10 \% \text { having an } \\
\text { occupancy greater than } 4\end{array}$ & $\begin{array}{l}\text { 85\% of CALEBRE properties had a household } \\
\text { size in the range of } 1 \text { and } 4 \text { occupants, with } 15 \% \\
\text { having an occupancy greater than } 4\end{array}$ \\
\hline
\end{tabular}


For the first sample of 9 houses (10 living rooms, 6 bedrooms), temperatures were recorded at hourly intervals from February 2010 to April 2010. Data for the period $11^{\text {th }}$ February to $24^{\text {th }}$ February 2010 were analysed and are presented in this study. This period is referred to as the 'winter study period'. For the remaining sample of 11 houses (10 living rooms and 11 bedrooms), temperatures were recorded at hourly intervals from April 2010 to May 2010. Data for the period $01^{\text {st }}$ April to $14^{\text {th }}$ April 2010 were analysed and are presented in this study and referred to as the 'spring study period'. Temperatures were recorded using $\mathrm{HOBO}$ temperature sensors (accuracy $\pm 0.35^{\circ} \mathrm{C}$ from $0^{\circ}$ to $50^{\circ} \mathrm{C}$ ) placed at approximately $1.5 \mathrm{~m}$ height above floor level, ensuring that they were not hidden behind or under furniture, and also ensuring that they were not exposed to direct sunlight or any other heat source.

\subsection{Analysis of CALEBRE data collected}

Summary statistics of the outdoor and indoor living room and bedroom temperatures recorded during the winter and spring study periods are given in Table 2. Outdoor temperature was recorded by the local weather station operated by the Department of Geography at Loughborough University. No house in the sample was more than 15 miles from this weather station. Average outdoor temperatures of $2.4^{\circ} \mathrm{C}$ and $8.4^{\circ} \mathrm{C}$ were recorded during the winter study period and spring study period, respectively. As shown in Table 2, a wide range of indoor temperatures, ranging from a minimum of $10.9^{\circ} \mathrm{C}$ to a maximum of $25.9^{\circ} \mathrm{C}$ were recorded during both study periods. However during the hours of evenings (18:00 to 24:00), average living room temperatures were $18.7^{\circ} \mathrm{C}\left(\mathrm{SD}= \pm 1.6^{\circ} \mathrm{C}\right)$ and $18.4^{\circ} \mathrm{C}$ ( $\mathrm{SD}= \pm 2.5^{\circ} \mathrm{C}$ ) for winter and spring study periods, respectively. Average of bedroom temperatures during the night $(00: 00$ to $06: 00)$ was $17.2^{\circ} \mathrm{C}\left(\mathrm{SD}= \pm 1.5^{\circ} \mathrm{C}\right)$ and $17.4^{\circ} \mathrm{C}(\mathrm{SD}=$ 
$\pm 2.5^{\circ} \mathrm{C}$ ) for winter and spring study periods, respectively. These time periods were selected as being those when living rooms and bedrooms were most likely to have been occupied. Hourly average, maximum and minimum temperatures ${ }^{2}$ recorded in living rooms during evenings (18:00 to 24:00) and in bedrooms during nights (00:00 to 06:00) together with outdoor temperatures for the winter study period (11-24 February 2010) and the spring study period (01-14 April 2010) are compared with the WHO recommended temperatures (Ranson, 1988) in Figure 1, Figure 2, Figure 3 and Figure 4. As shown in these figures, average hourly living room and bedroom temperatures were lower than the WHO recommended values of $21^{\circ} \mathrm{C}$ for living rooms and $18^{\circ} \mathrm{C}$ for bedrooms.

Table 0-2. Statistics of outdoor and indoor living room and bedroom temperatures recorded at hourly intervals during the winter study period (11-24 February 2010) and spring study period (01-14 April 2010) in solid wall houses near Loughborough, East Midlands, UK

\begin{tabular}{|c|c|c|c|}
\hline & $\begin{array}{c}\text { Average } \\
\left({ }^{\circ} \mathrm{C}\right)\end{array}$ & $\begin{array}{c}\text { Maximum } \\
\left({ }^{\circ} \mathrm{C}\right)\end{array}$ & $\begin{array}{c}\text { Minimum } \\
\left({ }^{\circ} \mathrm{C}\right)\end{array}$ \\
\hline \multicolumn{4}{|l|}{ Winter Study Period } \\
\hline Outdoor temperature & 2.4 & 11.2 & -2.7 \\
\hline Living room temperatures (00:00 to $24: 00 \mathrm{hrs}){ }^{(\mathrm{n}=10)}$ & 17.8 & 25.9 & 10.9 \\
\hline Living room temperatures (evenings,18:00 to $24: 00 \mathrm{hrs}){ }^{(\mathrm{n}=10)}$ & 18.7 & 23.2 & 12.3 \\
\hline Bedroom temperatures (00:00 to 24:00 hrs ) ${ }^{(\mathrm{n}=06)}$ & 17.6 & 23.6 & 11.3 \\
\hline Bedroom temperatures- night time (00:00 to 06:00 hrs) ${ }^{(\mathrm{n}=06)}$ & 17.2 & 20.7 & 11.6 \\
\hline \multicolumn{4}{|l|}{ Spring Study Period } \\
\hline Outdoor temperature & 8.4 & 17.8 & 1.3 \\
\hline Living room temperatures (00:00 to 24:00 hrs) $(\mathrm{n}=10)$ & 17.5 & 25.1 & 11.6 \\
\hline Living room temperatures (evenings,18:00 to 24:00 hrs) ${ }^{(n=10)}$ & 18.4 & 24.7 & 12.0 \\
\hline Bedroom temperatures (00:00 to 24:00 hrs) ${ }^{(n=11)}$ & 18.0 & 22.9 & 10.3 \\
\hline Bedroom temperatures- night time (00:00 to 06:00 hrs) ${ }^{(\mathrm{n}=11)}$ & 17.4 & 22.8 & 10.4 \\
\hline
\end{tabular}




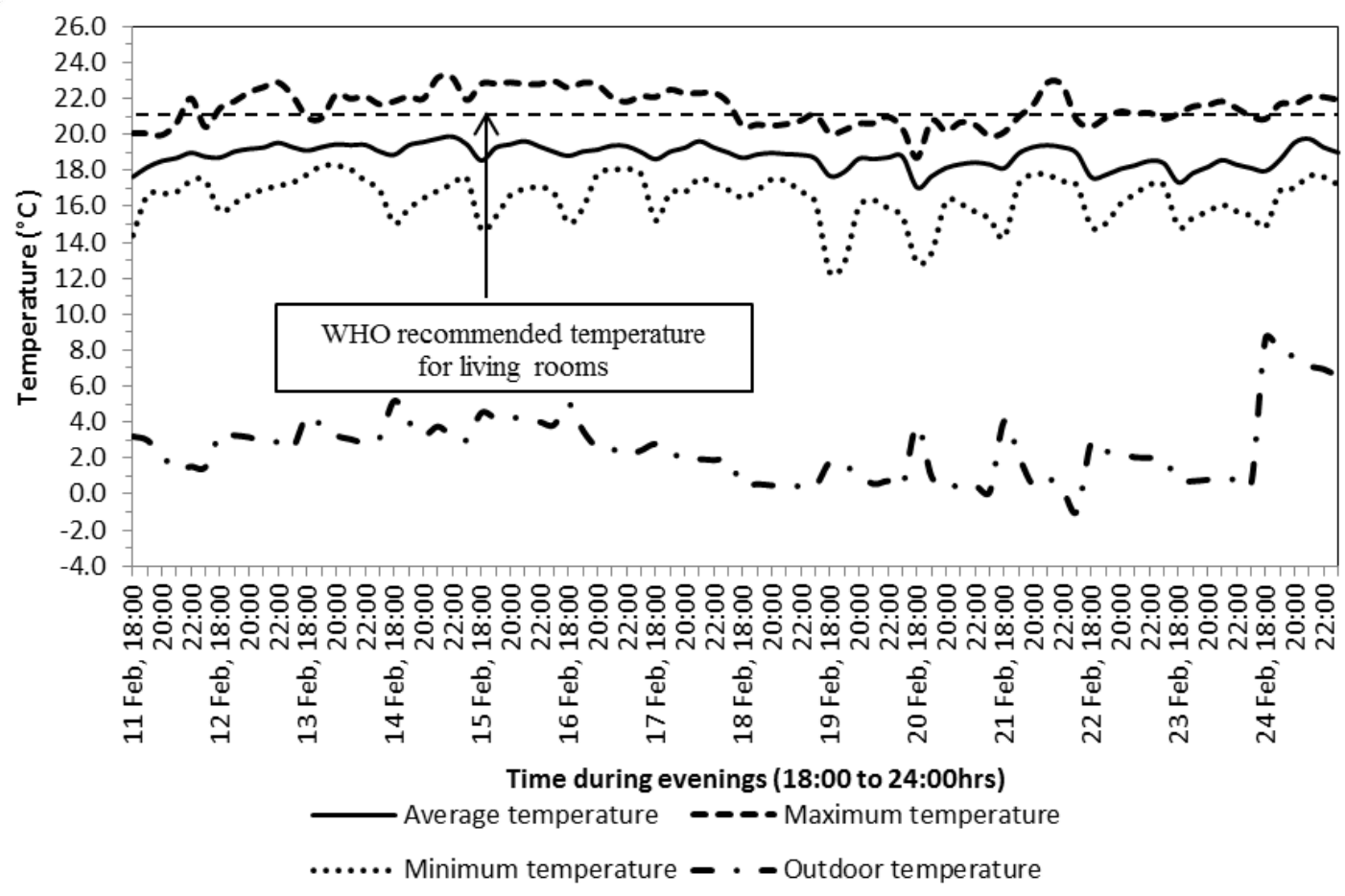

Figure 1: Hourly living room temperatures recorded during evenings (18:00 to 24:00hrs, 11-24 February 2010) in solid wall houses near Loughborough, East Midlands, UK, compared with the WHO recommended temperature (winter study period).

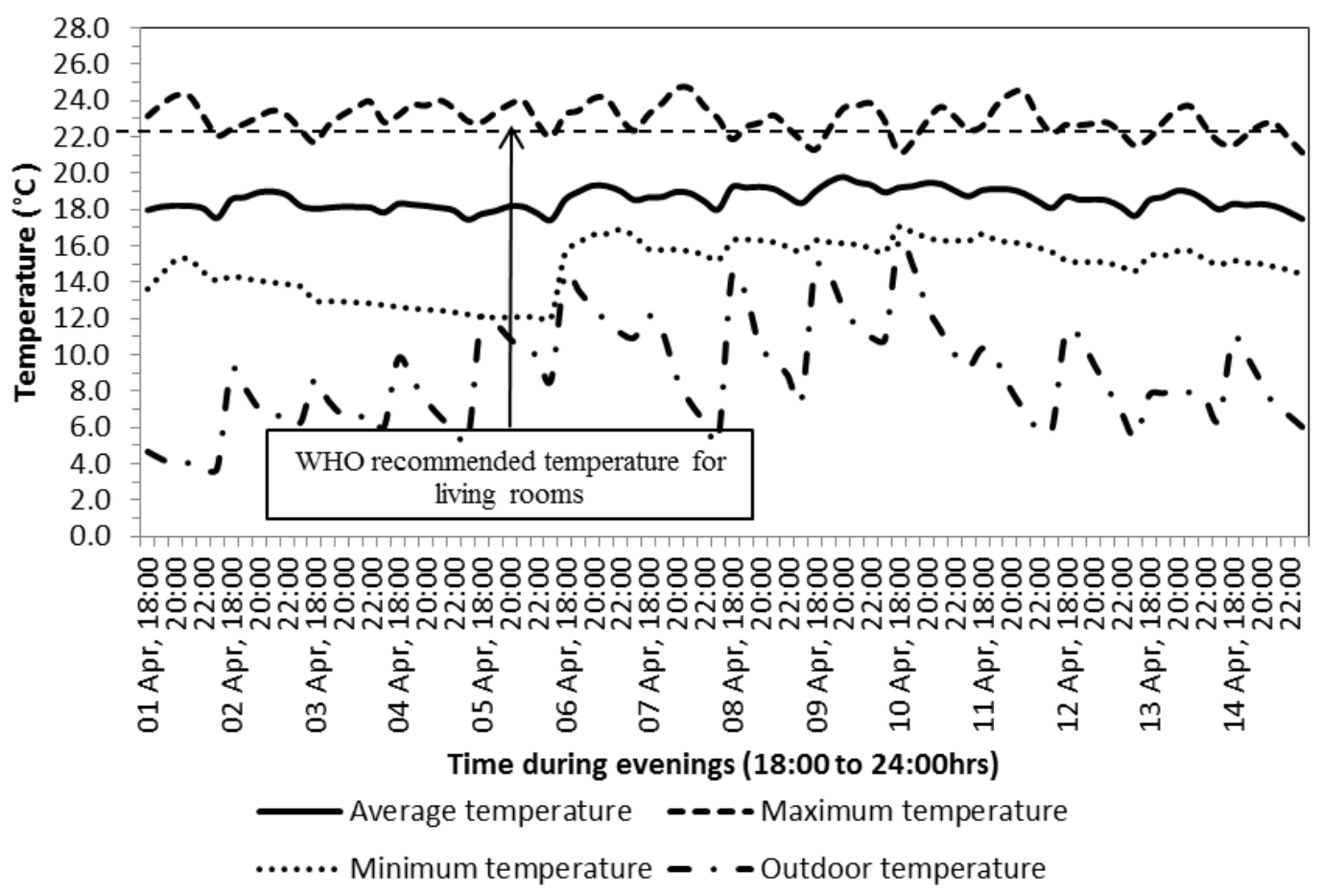


Figure 2: Hourly living room temperatures recorded during evenings (18:00 to 24:00hrs, 01-14 April 2010) in solid wall houses near Loughborough, East Midlands, UK, compared with the WHO recommended temperature (spring study period).

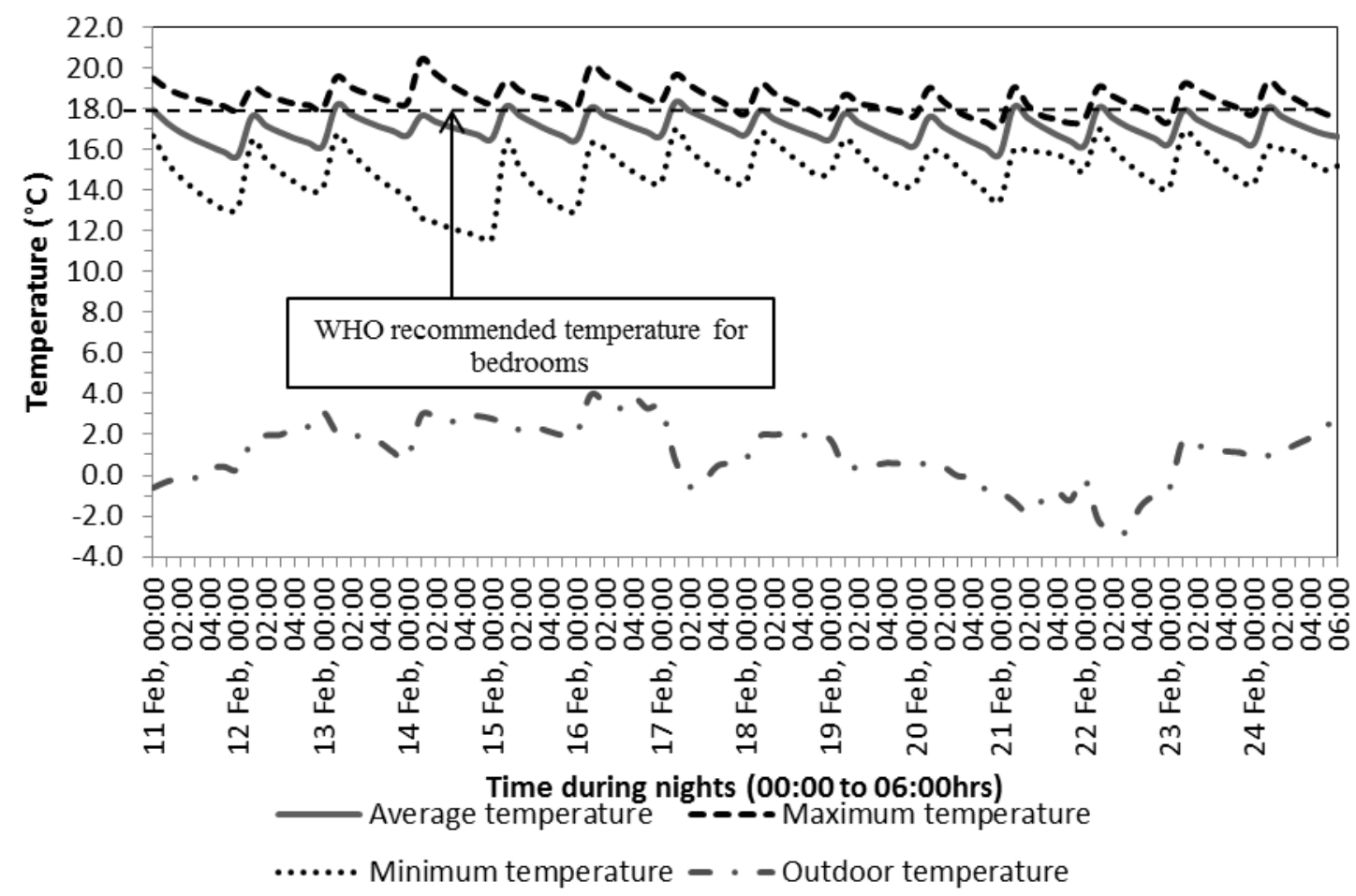

Figure 3: Hourly bedroom temperatures recorded during nights (00:00 to 06:00hrs, 11-24 February 2010) in solid wall houses near Loughborough, East Midlands, UK, compared with the WHO recommended temperature (winter study period).

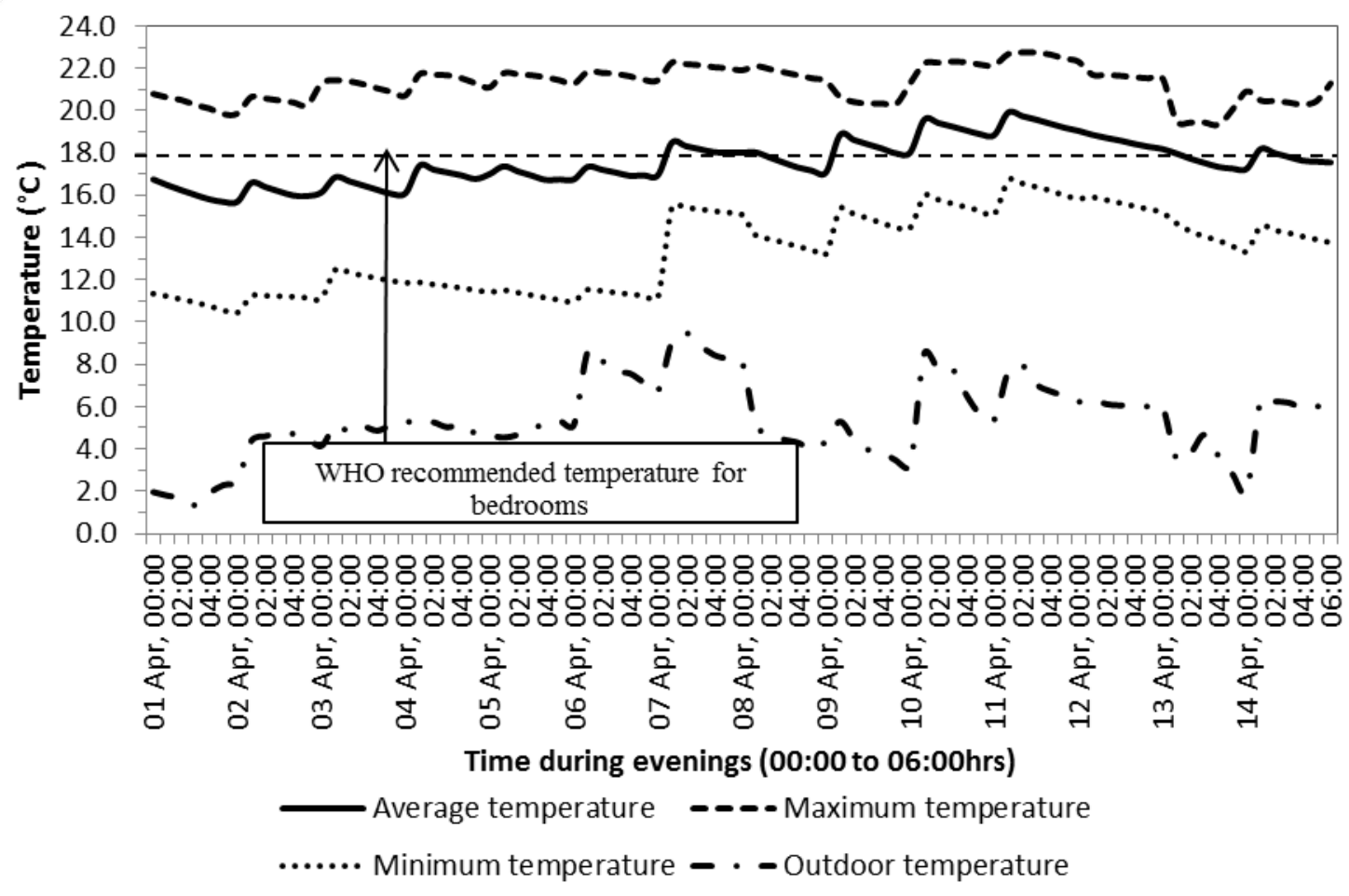


Figure 4: Hourly bedroom temperatures recorded during nights (00:00 to 06:00hrs, 01-14 April 2010) in solid wall houses near Loughborough, East Midlands, UK, compared with the WHO recommended temperature (spring study period).

\subsection{Percentage distribution of temperatures}

The percentage distribution of living room temperatures recorded during evenings (18:00 to 24:00hrs) and bedroom temperatures recorded during nights (00:00 to 06:00hrs) are shown in Figure 5. In living rooms, 93\% of temperatures recorded during the winter study period and $84 \%$ of temperatures recorded during the spring study period were below the WHO-recommended value of $21^{\circ} \mathrm{C}$. In bedrooms, $68 \%$ of temperatures recorded during the winter study period and 53\% of temperatures recorded during the spring study period were below the WHO-recommended value of $18^{\circ} \mathrm{C}$. A small proportion of temperatures were above the recommended values. In living rooms, $7 \%$ of temperatures recorded during the winter study period and $14 \%$ of temperatures recorded during the spring study period were above $21^{\circ} \mathrm{C}$. In bedrooms, $8 \%$ of temperatures recorded during the spring study period were above $18^{\circ} \mathrm{C}$, although none of the winter study temperatures were above $18^{\circ} \mathrm{C}$. These findings show that for the solid-walled houses investigated, a significant proportion of the temperatures recorded during periods of likely occupancy were below the WHOrecommended values of $21^{\circ} \mathrm{C}$ and $18^{\circ} \mathrm{C}$ suggesting that, either the householders choose to live at lower temperatures, or that these houses were not able to achieve and maintain the recommended temperatures. 


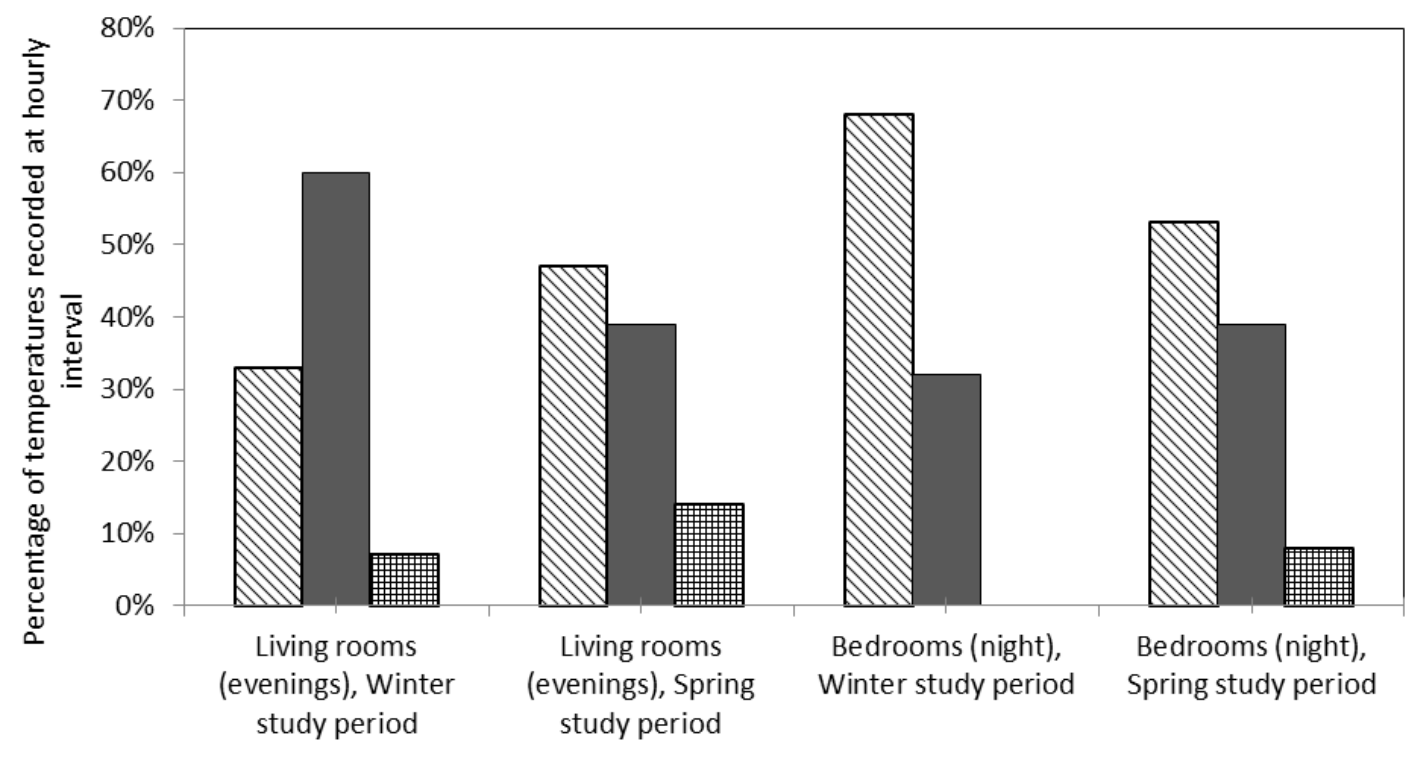

$\Delta$ less than $18^{\circ} \mathrm{C} \quad \square$ less than $21^{\circ} \mathrm{C}$ and greater than or equal to $18^{\circ} \mathrm{C} \quad \mathbf{P}^{\mathrm{T}}$ greater than or equal to $21^{\circ} \mathrm{C}$

Figure 5: Percentage distribution of temperatures in living rooms (evenings, 18:00 to 24:00) and bedrooms (nights, 00:00 to 06:00)

\subsection{Temperature variations according to time of day}

As shown in Figure 6 and Figure 7, during both study periods, average temperatures were lowest during nights (00:00-06:00) and mornings (06:00-09:00), gradually increased during the day time, and peaked during evenings suggesting operation of space heating during occupation. A high proportion of the CALEBRE houses had someone who was often at home in the day; almost half of the sample (45\%) fell into this category. 


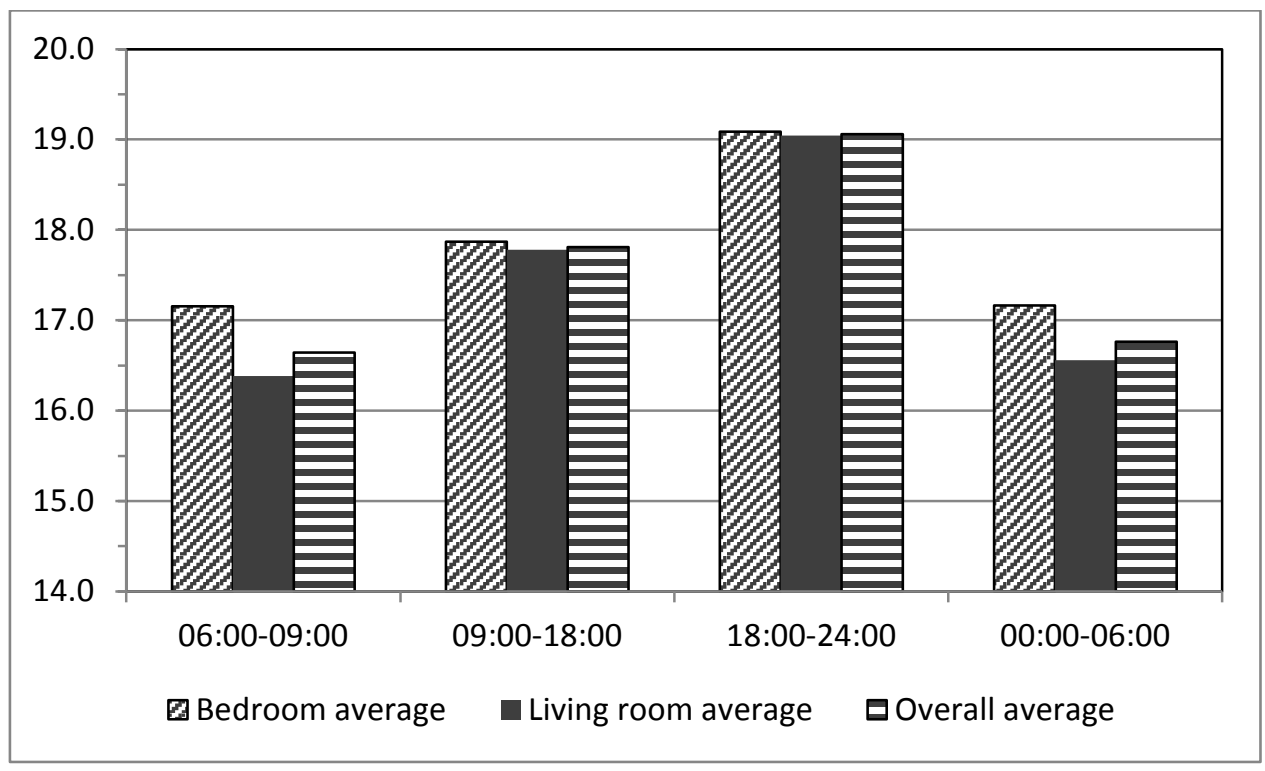

Figure 6: Average temperatures during time of day (winter study period)

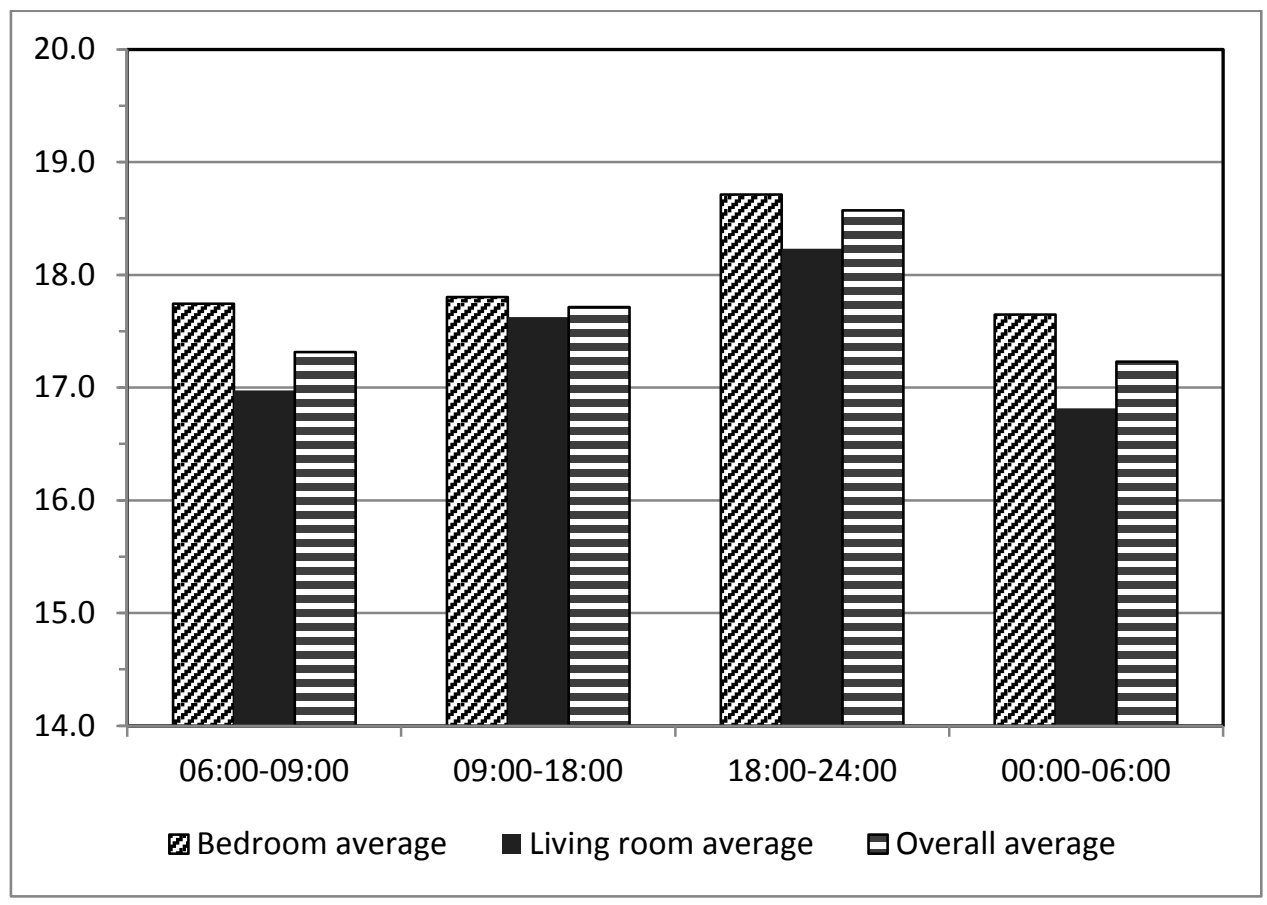

Figure 7: Average temperatures during time of day (spring study period)

The above data gathered during 2010 on solid-walled dwellings in Loughborough, as part of the CALEBRE project, were added to those from the historical review and are discussed later (in section 4). 


\subsection{Reported thermal comfort}

In addition to the quantitative temperature data collected in the CALEBRE sample, qualitative data were also gathered on thermal comfort sensations. Whilst this part of the study was not a full thermal comfort survey, nevertheless householders in the properties were asked to report times when they felt their thermal environment was uncomfortable. They were given a simple diary sheet to complete, identifying which member of the household was reporting the discomfort, the day, time and location in the house and in particular what they might have done to alleviate the discomfort. Data were collected over a period of several weeks in some cases, although not all instances of discomfort were noted. This information provides an insight into whether the temperatures measured in these homes were acceptable or not to their occupants. Any reported adaptive behaviours could suggest some dissatisfaction with the temperature, and that householders wanted some alternative conditions.

A total of 185 records gathered from 18 of the 20 households were analysed to determine the cause of any reported discomfort. Occupants were asked to report discomfort against the following categories: too hot, too cold, too draughty, too stuffy, too damp and too dry.

The suggested reasons for the discomfort and the action taken to alleviate it were also categorised. A total of $66 \%(n=123)$ of the diary records indicated that a householder felt that the local environment was too cold at a particular time, almost $22 \%(n=40)$ records showed it was too hot, almost $8 \%(n=14)$ too draughty and of the remainder: $2 \%$ too damp, $2 \%$ too stuffy and $1 \%$ too dry. The fact that the majority of records from householders stated that they were too cold suggests that the internal temperatures were generally lower 
than people wanted, the reasons for which require further consideration. It is possible that the homes were too cold because the householders were not able to heat their homes to a higher temperature (perhaps because of an inefficient heating system or as a result of heat losses) or because they chose not to heat their homes sufficiently. Explanations given by the householders for why the room or house was too cold are shown in Table 0-3.

Table 0-3. Reported reasons for being too cold.

\begin{tabular}{lcc}
\hline Reason for being too cold & Number of records & $\begin{array}{c}\text { Percentage of total too cold } \\
(\mathbf{n = 1 2 3 )}\end{array}$ \\
\hline Heating not on & 45 & $37 \%$ \\
\hline Inadequate heating in the room & 22 & $18 \%$ \\
\hline Inactivity - Sitting still & 11 & $9 \%$ \\
\hline Particularly cold night or day & 10 & $8 \%$ \\
\hline Draught of cold from another room & 9 & $7 \%$ \\
\hline Heating had gone off & 7 & $6 \%$ \\
\hline Heating was turned down & 5 & $4 \%$ \\
\hline Just come in from a warmer room & 3 & $2 \%$ \\
\hline Heating only just come on & 3 & $2 \%$ \\
\hline Insufficient clothes on & 3 & $2 \%$ \\
\hline Heating not working properly & 2 & $2 \%$ \\
\hline
\end{tabular}

These results show that the main reason reported for a householder being too cold was that the heating was not turned on in their house or the room in which they were located. In some cases, this was because the heating was programmed to come on at a later time. In other cases, the householder did not use their central heating system and instead switched on a local heater once they entered a particular room. Examples of comments included the following:

- 'Got up early, the heating is not on properly yet' (Female, 6:15 am)

- 'Heating not on at that time' (Male, 10:30pm)

- 'Been out, the house was cold' (Male, 4:00pm)

In some cases, the heating was on in the room, but the temperature was not sufficiently high: 
- 'Cold outside and heating not up too high' (Female, 5.40pm)

- 'Checked and found the thermostat had been turned to $19\left({ }^{\circ} \mathrm{C}\right)$, not enough!' (Female, 7:45pm)

The cases where the heating was not working properly related to temporary faults rather than poor efficiency. The action taken by householders in response to these cold conditions showed interesting results, as shown in Table 0-4. In many cases, householders did more than one thing in order to feel warmer, so total percentages add up to more than $100 \%$.

Table 0-4. Reported adaptive behaviours taken by householders

\begin{tabular}{lcc}
\hline Adaptive behaviour taken & Number of records & $\begin{array}{c}\text { Percentage of total too cold } \\
(\mathbf{n = 1 2 3 )}\end{array}$ \\
\hline Put on more clothing & 42 & $34 \%$ \\
\hline Put on a local heater & 30 & $24 \%$ \\
\hline Turn up the heating & 22 & $18 \%$ \\
\hline Turn on the heating & 18 & $15 \%$ \\
\hline Use a blanket or throw & 12 & $10 \%$ \\
\hline Shut doors & 9 & $7 \%$ \\
\hline Nothing & 5 & $4 \%$ \\
\hline Move nearer the heat source & 4 & $3 \%$ \\
\hline Be more active & 2 & $2 \%$ \\
\hline Move to a location somewhere warmer & 3 & $2 \%$ \\
\hline Eat some hot food or drink & 3 & $1 \%$ \\
\hline Close the window & 1 & $1 \%$ \\
\hline Close the curtains & 1 & $1 \%$ \\
\hline Take a hot bath & 1 & $1 \%$ \\
\hline Go to bed & 1 & \\
\hline
\end{tabular}




\subsection{Discussion}

\subsection{A comparison of measured and recommended temperatures in homes}

In this final part of the paper, we return to the data reviewed in Section 2 supplemented by that of the CALEBRE study described in Section 3, synthesise and present these data graphically, and then discuss the findings and potential implications. The World Health Organisation (WHO) conducted a review of evidence from scientific and epidemiological European studies that investigated adverse effects on health of low indoor temperatures, particularly in high-risk groups. In 'Guidelines for healthy housing' (Ranson, 1988) the WHO recommended minimum domestic temperatures of $21^{\circ} \mathrm{C}$ for living rooms and $18^{\circ} \mathrm{C}$ for bedrooms. In addition to the WHO, the British Standards (BSI, 2005) specify a temperature range of $18-21^{\circ} \mathrm{C}$ in winter for dwellings that have mechanical heating and cooling. The CIBSE Guide A (CIBSE, 2011) recommends a temperature range of $20-22^{\circ} \mathrm{C}$ for living rooms and $17-19^{\circ} \mathrm{C}$ for bedrooms in winter. Temperatures of $21^{\circ} \mathrm{C}$ in living rooms and $18^{\circ} \mathrm{C}$ in bedrooms are also considered to be in the comfort range by the UK Government (DEFRA, 2008), and are currently being used by the software RdSAP to calculate a dwelling's energy efficiency (DECC, 2009).

Average living room and average bedroom temperatures measured over the period 1969 to 2010 and relating largely to occupied periods ${ }^{3}$ (unless otherwise stated) in winter and spring time have been plotted and are shown in Figure 8, where they are compared with WHO-recommended temperatures. Table 5 accompanies Figure 8, and presents summary statistics (not exhaustive) to provide some measure of dispersion relating to the points in Figure 8. Inspection suggests that many winter and spring-time living room temperatures measured during largely-occupied periods have been historically lower than the WHOrecommended temperature of $21^{\circ} \mathrm{C}$. The CALEBRE study recorded average living room 
temperatures of $18.7^{\circ} \mathrm{C}$ in solid-walled dwellings, with a significant proportion of temperatures lower than the WHO-recommended value.

There have been a limited number of studies conducted of bedroom temperatures.

Inspection of available data in Figure 8 together with their corresponding statistics in Table 5 suggest that many of the measured bedroom temperatures before the 1980 s have been lower than the WHO-recommended value of $18^{\circ} \mathrm{C}$, having increased after the 1980 s, to remain mostly in the range of 18 to $21^{\circ} \mathrm{C}$. The CALEBRE study recorded an average bedroom temperature of $18.1^{\circ} \mathrm{C}$.

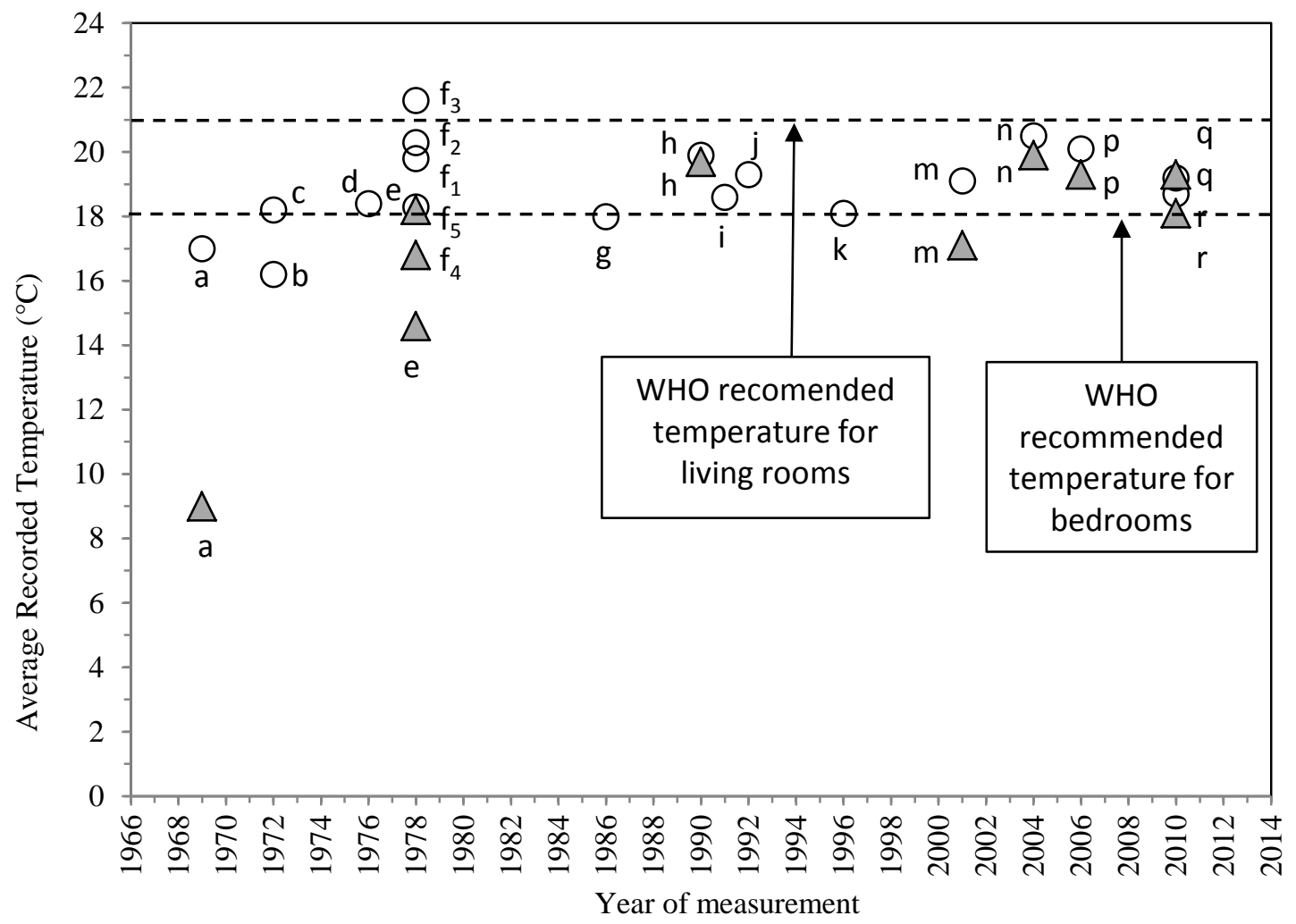

OAverage Living Room Temperatures $\quad \Delta$ Average Bedroom Temperatures

Figure 8: Trend of average internal temperatures recorded largely during occupied periods (unless otherwise stated) in UK dwellings from 1969 to 2010.

\footnotetext{
a. Modern flats ${ }^{\mathrm{n}=72}$, elderly residents, located in Birmingham, 1969, occupied (Collins, 1986).

b. Various house types, elderly residents ${ }^{\mathrm{n}=973}$, spread across the UK, 1972, occupied (Fox et al. 1973).

c. Various house types, elderly residents ${ }^{\mathrm{n}}=47$, located in London Borough of Camden, 1972, occupied (Fox et al. 1973).

d. Same house and residents as in 'c', 1975-6, occupied (Collins et al. 1977).

e. Various house types, various types of residents ${ }^{\mathrm{n}}=1000$, spread across the UK, 1978, occupied (Hunt \& Gidman, 1982).

$\mathrm{f}_{1}$. Uninsulated homes ${ }^{\mathrm{n}=15}$, various types of residents, 1977-1978, occupied (Nevrala \& Pimbert, 1981).
} 
$f_{2}$. Retrofit insulated homes ${ }^{n}=16$, various types of residents, 1977-1978, occupied (Nevrala \& Pimbert, 1981).

$f_{3}$. New-built well insulated homes ${ }^{n=7}$, various types of residents, 1977-1978, occupied (Nevrala \& Pimbert, 1981).

$\mathrm{f}_{4}$. Uninsulated homes ${ }^{n=15}$, various types of residents, 1977-1978, very likely occupied (Nevrala \& Pimbert, 1981).

$\mathrm{f}_{5}$. Retrofit insulated homes ${ }^{\mathrm{n}=16}$, various types of residents, 1977-1978, very likely occupied (Nevrala \& Pimbert, 1981).

g. Various house types ${ }^{\mathrm{n}=2177}$, various types of residents, spread across the UK, 1986, occupied (DOE, 1995).

h. Low energy home ${ }^{\mathrm{n}=14}$, various types of residents ${ }^{\mathrm{n}=38}$, located in Milton Keynes, 1989-91, occupancy may vary (Summerfield et al. 2007).

i. Various house types ${ }^{n=25000}$, various types of residents, spread across the UK, 1991, occupied (DOE, 1996).

j. Owner-occupied homes ${ }^{\mathrm{n}=860}$ of similar size and design, with cavity and loft insulation, double glazing, built during 1998-1990 by only 2-3 different building companies, various types of residents, spread across the UK, 1991-92, occupied (Oseland, 1994).

k. Various house types ${ }^{n=\text { Unknown. }}$, various types of residents, spread across the UK, 1996, occupied (DETR, 2000).

m. Various house types ${ }^{\mathrm{n}}=1600$, various types of residents, spread across the UK, 2005-06, occupancy may vary (Oreszczyn et al. 2006).

n. Various house types ${ }^{n=25}$, various types of residents, spread across the Northern Ireland, 2007, occupancy may vary (Yohanis \& Mondol, 2010).

p. Same houses and residents as in 'h', 2006, occupancy may vary (Summerfield et al. 2007).

q. Various house types ${ }^{n=12}$, various types of residents, spread across the Midlands, 2009-10, occupancy may vary (E.ON, 2010).

r. Solid wall house ${ }^{\mathrm{n}=20}$, various types of residents (owners) ${ }^{\mathrm{n}=56}$, located in and around Loughborough, 2009-10, very likely occupied.

Table 0-5 Summary statistics (not exhaustive) relating to the points shown in Figure 8, gathered from the papers reviewed

\begin{tabular}{|c|c|c|c|c|c|c|c|c|c|}
\hline $\begin{array}{c}\text { Year of } \\
\text { study } \\
\& \\
\text { Point } \\
\text { in Fig.8 }\end{array}$ & $\begin{array}{c}\text { Averag } \\
\text { e } \\
\text { Living } \\
\text { Room } \\
\text { Temp, } \\
{ }^{\circ} \mathrm{C}\end{array}$ & $\begin{array}{c}\text { Std } \\
\text { Dev } \\
\text { (Living } \\
\text { Room), } \\
{ }^{0} \mathrm{C}\end{array}$ & $\begin{array}{l}\text { Max. } \\
\text { Living } \\
\text { Room } \\
\text { Temp, } \\
{ }^{0} \mathrm{C}\end{array}$ & $\begin{array}{l}\text { Min. } \\
\text { Living } \\
\text { Room } \\
\text { Temp, } \\
{ }^{0} \mathrm{C}\end{array}$ & $\begin{array}{c}\text { Averag } \\
\text { e } \\
\text { Bedroo } \\
\text { m } \\
\text { Temp, } \\
{ }^{\circ} \mathrm{C}\end{array}$ & $\begin{array}{c}\text { Std } \\
\text { Dev } \\
\text { (Bedro } \\
\text { om), }{ }^{\circ} \mathrm{C}\end{array}$ & $\begin{array}{c}\text { Max. } \\
\text { Bedroo } \\
\text { m } \\
\text { Temp, } \\
{ }^{0} \mathrm{C}\end{array}$ & $\begin{array}{c}\text { Min. } \\
\text { Bedroo } \\
\text { m } \\
\text { Temp, } \\
{ }^{\mathbf{0}} \mathbf{C}\end{array}$ & $\begin{array}{c}\text { Publica } \\
\text { tion }\end{array}$ \\
\hline $\begin{array}{c}1969 \\
\mathrm{a}\end{array}$ & 17 & NR & NR & NR & 9 & NR & NR & NR & $\begin{array}{c}\text { Depart } \\
\text { ment of } \\
\text { Social } \\
\text { medicin } \\
\text { e, } \\
\text { Birming } \\
\text { ham } \\
\text { Univers } \\
\text { ity, }\end{array}$ \\
\hline $\begin{array}{c}1972 \\
\mathrm{~b}\end{array}$ & 16.2 & 3.27 & NR & NR & NR & NR & NR & NR & $\begin{array}{c}\text { Fox et } \\
\text { al } \\
(1973)\end{array}$ \\
\hline $\begin{array}{c}1972 \\
\text { c }\end{array}$ & 18.2 & 3.15 & NR & NR & NR & NR & NR & NR & $\begin{array}{c}\text { Fox et } \\
\text { al } \\
(1973) \\
\text { and } \\
\text { Collins } \\
\text { et al } \\
(1977) \\
\end{array}$ \\
\hline $\begin{array}{c}1976 \\
d\end{array}$ & 18.4 & 2.69 & NR & NR & NR & NR & NR & NR & $\begin{array}{c}\text { Collins } \\
\text { et al } \\
(1977)\end{array}$ \\
\hline $\begin{array}{c}1978 \\
\mathrm{e}\end{array}$ & 18.3 & 3 & NR & NR & 14.6 & 3.3 & NR & NR & $\begin{array}{c}\text { Hunt } \\
\text { and } \\
\text { Gidman } \\
\text { (1982) }\end{array}$ \\
\hline $\begin{array}{c}1981 \\
\mathrm{f}_{1} \& \mathrm{f}_{4}\end{array}$ & 19.8 & NR & 25 & 16 & $16.8^{+}$ & NR & $24^{x}$ & $10^{\mathrm{x}}$ & $\begin{array}{l}\text { Nevrala } \\
\text { and } \\
\text { Pimbert } \\
(1981)\end{array}$ \\
\hline $\begin{array}{r}1981 \\
\mathrm{f}_{2} \& \mathrm{f}_{5}\end{array}$ & 20.3 & NR & 26 & 16 & $18.2^{+}$ & NR & $24^{\mathrm{x}}$ & $10^{\mathrm{x}}$ & $\begin{array}{c}\text { Nevrala } \\
\text { and }\end{array}$ \\
\hline
\end{tabular}




\begin{tabular}{|c|c|c|c|c|c|c|c|c|c|}
\hline & & & & & & & & & $\begin{array}{c}\text { Pimbert } \\
(1981) \\
\end{array}$ \\
\hline $\begin{array}{c}1981 \\
\mathrm{f}_{3}\end{array}$ & 21.6 & NR & 26 & 16 & NR & NR & NR & NR & $\begin{array}{c}\text { Nevrala } \\
\text { and } \\
\text { Pimbert } \\
(1981)\end{array}$ \\
\hline $\begin{array}{c}1986 \\
\mathrm{~g}\end{array}$ & 18 & 3.1 & 27.3 & 4.5 & NR & NR & NR & NR & $\begin{array}{l}\text { EHCS } \\
(1986) \\
\end{array}$ \\
\hline $\begin{array}{c}1990 \\
\mathrm{~h}\end{array}$ & $19.9^{+}$ & NR & $20 * *$ & $19.8 * *$ & $19.7^{+}$ & NR & $19.8^{* *}$ & $19.6^{* *}$ & $\begin{array}{c}\text { Summe } \\
\text { rfield et } \\
\text { al } \\
(2007) \\
\end{array}$ \\
\hline $\begin{array}{c}1991 \\
\mathrm{i}\end{array}$ & 18.6 & NR & NR & NR & NR & NR & NR & NR & $\begin{array}{l}\text { EHCS } \\
(1991) \\
\end{array}$ \\
\hline $\begin{array}{c}1992 \\
\mathrm{j}\end{array}$ & $19.2^{\mathrm{xx}}$ & 2.2 & NR & NR & NR & NR & NR & NR & $\begin{array}{c}\text { Oseland } \\
\text { (1994) }\end{array}$ \\
\hline $\begin{array}{c}1996 \\
k\end{array}$ & 18.1 & NR & NR & NR & NR & NR & NR & NR & $\begin{array}{l}\text { EHCS } \\
(1996)\end{array}$ \\
\hline $\begin{array}{c}2001 \\
\mathrm{~m}\end{array}$ & $19.1^{++}$ & NR & $23^{*}$ & $13.5^{*}$ & $17.1^{++}$ & NR & 21.8* & $12.1^{*}$ & $\begin{array}{c}\text { Oreszcz } \\
\text { yn et al } \\
(2006)\end{array}$ \\
\hline $\begin{array}{c}2004 \\
\mathrm{n}\end{array}$ & 20.5 & NR & $23.9^{\#}$ & $16^{\#}$ & 19.9 & NR & $23.9^{\#}$ & $16^{\#}$ & $\begin{array}{c}\text { Yohanis } \\
\text { and } \\
\text { Mondol } \\
\text { l (2010) }\end{array}$ \\
\hline $\begin{array}{c}2006 \\
p\end{array}$ & $20.1^{+}$ & NR & $20.3^{* *}$ & $19.8^{* *}$ & $19.3^{+}$ & NR & $19.6^{* *}$ & $19.1^{* *}$ & $\begin{array}{c}\text { Summe } \\
\text { rfield et } \\
\text { al } \\
(2007)\end{array}$ \\
\hline $\begin{array}{c}2010 \\
q\end{array}$ & 19.2 & 2.9 & 26.9 & 14.7 & 19.3 & 2.8 & 27.1 & 11.8 & $\begin{array}{l}\text { Challen } \\
\text { ge } 100\end{array}$ \\
\hline $\begin{array}{c}2010 \\
r\end{array}$ & 18.7 & 2.3 & 25.9 & 12.0 & 18.1 & 2.2 & 23.6 & 10.7 & $\begin{array}{l}\text { CALEB } \\
\text { RE }\end{array}$ \\
\hline \multicolumn{10}{|c|}{ NR = not reported, not available or not applicable } \\
\hline \multicolumn{10}{|c|}{$* *=95 \%$ confidence interval reported } \\
\hline \multicolumn{10}{|c|}{${ }^{+}=$for, or standardized to, an external temperature of $+5^{\circ} \mathrm{C}$} \\
\hline \multicolumn{10}{|c|}{${ }^{++}=$median values, for standardized external temperature of $+5^{\circ} \mathrm{C}$} \\
\hline \multicolumn{10}{|c|}{$\mathrm{x}=$ for a mean diurnal (external) temperature between $-2^{\circ} \mathrm{C}$ and $0^{\circ} \mathrm{C}$} \\
\hline $\mathrm{xx}=$ for & an outd & mpe & e of 12 . & & & & & & \\
\hline
\end{tabular}

\subsection{Have domestic indoor temperatures risen over the last 40 years?}

There exists a popular belief that temperatures in UK homes have risen over the last few decades, but to what extent is this actually the case? Work by Utley and Shorrock (2008) suggests that indoor domestic temperatures have risen. However, their reference is to that 
of an increase in whole house temperatures, with estimates of temperature rise being predominantly based on modelling work together with findings from a limited selection of measured data. Our synthesis and presentation in Figure 8 of a large selection of measured data shows a generally horizontal trend, suggesting that there has been little or no increase in winter and spring-time average living room temperatures measured during largelyoccupied periods over the last 40 years.

However,, bedroom winter and spring-time average temperatures measured during largelyoccupied periods do appear to have increased over the last 40 years, though this is based only on the limited data available. Any increase in average bedroom temperatures would, however, be consistent with the historical growth of domestic central heating installations, as well as reduction in whole house heat loss. It has been noted (Utley \& Shorrock, 2008) that central heating ownership has increased from 30\% in 1969 to 55\% in 1979 and to $75 \%$ in 1990. Considering average living room and average bedroom temperatures together, there would have been a slight increase in whole house temperature, consistent with the preceding discussion. Shipworth et al. (2010) found no statistical evidence for changes in reported thermostat settings in English homes between 1984 and 2007, suggesting that the extent of dwelling area heated, amongst other things, might explain why domestic heating energy use has not declined despite efficiency improvements. The lack of change in reported thermostat setting would be in accord with the findings we present in this paper.

\subsection{Indoor domestic thermal comfort}

Compared with thermal comfort investigations in commercial and office environments, there have been relatively fewer studies on domestic thermal comfort, either in the UK or elsewhere. For the UK, Oseland's study (Oseland, 1994) concluded that reported neutral 
temperatures were lower than those predicted by ISO7730 (BSI, 2005). A further study by Oseland (1995) found a context effect, namely that reported neutral temperatures in homes were lower than those in offices and climate chambers, for the same set of subjects. The paper suggested that adaptive actions in the domestic context could have been responsible for these differences.

Oreszczyn et al. (2006) reported on the effects of domestic energy efficiency measures taken under England's 'Warm Front' programme, observing that these led to substantial improvements of both living room and bedroom temperatures and that these are likely to have benefits in terms of thermal comfort. This was reported in more detail by Hong et al. (2009), who described surveys that were carried out in Warm Front households before and after energy efficiency upgrades. The surveys involved collection of self-reported thermal comfort votes on a seven point thermal sensation scale and recording of indoor temperatures in living rooms and bedrooms twice during the day. The findings state that the efficiency measures led to increased indoor temperatures, increased thermal comfort and showed a take-back effect. The 'Predicted Mean Vote' (PMV) was found to underpredict actual thermal comfort conditions. The PMV is an index that predicts the mean value of the votes of a large group of persons on the 7-point thermal sensation scale, based on the heat balance of the human body (BSI, 2005).

It has been suggested that, after receiving energy efficiency upgrades, people may consider a whole house temperature of $20^{\circ} \mathrm{C}$ to be the most likely comfort temperature (Milne \& Boardman, 2000). Utley and Shorrock (2008) suggest that the overall comfort level in insulated, centrally-heated homes might be around $19-20^{\circ} \mathrm{C}$. They also report German work which suggests that, in low energy 'passive' houses, people regard a mean internal 
temperature of $22^{\circ} \mathrm{C}$ as comfortable. Qualitative data gathered on reported thermal comfort from the CALEBRE study (section 3.5) suggests that there may be some degree of dissatisfaction with living room temperatures in solid-wall dwellings, many of these being significantly lower than the WHO-recommended value of $21^{\circ} \mathrm{C}$.

These studies imply that, in order to improve thermal satisfaction, living room temperatures may need to be maintained within the range $20-22^{\circ} \mathrm{C}$. However, this is based on a very limited number of studies, and it is recommended that a thorough investigation of domestic thermal comfort and comfort temperatures be conducted before definite recommendations are made that inform policy.

Any increases in indoor domestic temperatures that are considered essential (on health or comfort grounds for example) should, as far as possible, be achieved by improving the energy efficiency of the house. This highlights the need for refurbishment (better insulation, reduction in heat losses and efficient heating systems and controls) as energy efficient means to achieve higher temperatures and thermal satisfaction in homes where this is needed (i.e. beneficial 'takeback' - see below). The UK Government’s Green Deal Policy (HMSO, 2011) offers an important opportunity towards addressing this need.

\subsection{Considerations for Future Policy}

We end our discussion by offering some thoughts and comments for potential consideration in development of future policy.

The software 'RdSAP' is currently used in the UK Government's 'Green Deal' policy for assessing the reduction in energy consumption to be expected following a domestic 
efficiency upgrade. RdSAP calculations are based on assumed indoor temperatures of $21^{\circ} \mathrm{C}$ for living rooms and $18^{\circ} \mathrm{C}$ for bedrooms. Our finding that many actual living room temperatures during largely-occupied periods in winter and spring have been lower than the $21^{\circ} \mathrm{C}$ value assumed in RdSAP could impact upon expected energy savings, payback times, and consequent fulfillment of the Green Deal's 'Golden Rule'. It is recommended that consideration be given to accounting for this in domestic energy and payback assessments.

Many temperatures in living rooms during winter and spring, and for periods when occupation was likely, have been lower than that recommended by the World Health Organisation (WHO). Whilst beyond the scope of this paper, it may be reasonable to infer some connection between this and potential cost burdens upon Britain's National Health Service (NHS). Cost-benefit analyses of the return on investment that could accrue from preventing Fuel Poverty suggest that, for every $£ 1$ spent on reducing Fuel Poverty, a return in NHS savings of 42 pence can be expected from health gains (Liddell, 2008). A household is in Fuel Poverty if, in order to maintain an acceptable level of temperature throughout the home, the occupants would have to spend more than $10 \%$ of their income on all household fuel use (DEFRA, 2008). Therefore, some instances of occupant 'takeback' in the form of raised living room temperatures following an efficiency upgrade could be viewed as beneficial, with the possibility of reduced longer-term costs to the NHS. This could open future debate as to whether people have 'a right' to be able to achieve a particular indoor temperature on health and thermal comfort grounds, with excesses being discouraged in some way. 
Our evidence of there having been little change in winter and spring-time indoor average living room temperatures over the last forty years tempts one to speculate whether there might be little or no change in such indoor winter and spring-time temperatures over the coming forty years (notwithstanding any takeback effects). Viewing this scenario against the background of predicted increasing outdoor temperatures to be expected as a result of climate change, alongside increasing numbers of homes being refurbished for energy efficiency, should mean improved energy savings that will help the UK towards achieving its 2050 carbon reduction target. As regards the summer period, however, the question of overheating in refurbished dwellings is also receiving attention (Beizaee et al. 2013). Policymakers might give some thought as to how potential future overheating risks might be estimated and minimised as part of current policy-driven energy refurbishment interventions, together with householders being discouraged from future active reduction of summertime indoor temperatures through domestic air-conditioning, for example.

\subsection{Conclusions}

A review of measured data drawn from studies conducted over four decades on winter and spring-time living room and bedroom temperatures in UK homes has been presented in this paper together with analysis of measured data from the recent CALEBRE study. A discussion of thermal comfort in UK homes has also been presented, based on the limited data available to date. Conclusions are as follows:

- For periods when occupation was likely, little or no increase in average winter and spring-time actual living room temperatures appears to have taken place in UK homes over the last 40 years, based on reported measured data, with many recorded living room temperatures having been historically lower than the WHO-recommended value of $21^{\circ} \mathrm{C}$. 
- Correspondingly, for periods of likely occupation, there appears to have been an increase in average winter and spring-time bedroom temperatures over the same period, though this is based on limited available data. This increase can likely be attributed to growth in central heating ownership, together with reductions in whole-house heat loss. From 1990 onwards, average recorded bedroom temperatures have been near to, or above, the WHO-recommended value of $18^{\circ} \mathrm{C}$. Consequently, whole-house temperatures appear to have slightly increased.

- Compared with non-domestic buildings, there have been fewer investigations of domestic thermal comfort, either in the UK or elsewhere. Based on suggestions from the limited range of studies available for the UK situation, living room temperatures may need to be maintained within the range $20-22^{\circ} \mathrm{C}$ for thermal satisfaction. However, further detailed investigations of domestic indoor temperatures during occupied hours and domestic thermal comfort are required before definite recommendations can be made.

- Improving the energy efficiency of homes should be the primary means to effect such increases in winter and spring-time indoor temperatures that are deemed as essential, for example on health grounds. The UK Government's Green Deal Policy offers an opportunity to achieve this, possibly alongside enhanced thermal satisfaction. At the same time, consideration should be given to curbing excessive 'takeback' .

- Many winter and spring-time actual living room temperatures have historically been less than the value of $21^{\circ} \mathrm{C}$ assumed in software used by Green Deal assessors in recommending whole-house domestic energy efficiency refurbishment packages. Policymakers should consider how this might be taken into account when estimating savings and payback times within the confines of the Green Deal's 'Golden Rule'. Further considerations for future policy development should include the relationships 
between actual domestic indoor living temperatures, take-back, health, and future overheating risk.

\section{Acknowledgments}

This work forms part of the CALEBRE Project which is funded by the Research Councils UK Energy Programme and E.ON, to whom the authors express their gratitude. Thanks are also extended to the participants, without whom this study would not have been possible. For further information on the CALEBRE Project, email Dennis Loveday, Loughborough University, d.l.loveday@lboro.ac.uk.

\section{References}

Beizaee, A., Lomas, K.J. \& Firth, S.K., 2013. National survey of summertime temperatures and overheating risk in English homes. Building and Environment, 65(July), pp.1-17. Available at: http://dx.doi.org/10.1016/j.buildenv.2013.03.011 [Accessed May 28, 2013].

BSI, 2005. BS EN ISO 7730:2005-Ergonomics of the thermal environment - Analytical determination and interpretation of thermal comfort using calculation of the PMV and PPD indices and local thermal comfort criteria.

CIBSE, 2011. CIBSE Guide A- Environmental design, London: British Standard Institution. Available at: http://www.ncbi.nlm.nih.gov/pubmed/21806225.

Collins, K.J. et al., 1977. Accidental hypothermia and impaired temperature homoeostasis in the elderly. British Medical Journal, 1, pp.353-356.

Collins, K.J., 1986. Low indoor temperatures and morbidity in the eldery. Age and Ageing, 15, pp.212-220.

DECC, 2011. Annual report on fuel poverty statistics 2011, London, UK. 
DECC, 2009. The Government's Standard Assessment Procedure for Energy Rating of Dwellings, London, UK.

DEFRA, 2008. The UK Fuel Poverty Strategy. 6th Annual Progress Report, London.

DETR, 2000. The English House Condition Survey 1996, London.

DOE, 1995. English House Condition Survey 1986,

DOE, 1996. English House Conditions Survey 1991, London.

E.ON, 2010. Challenge 100. Tackling fuel poverty for 100 families, in 100 homes, in 100 days., Coventry, UK.

Fox, R.H. et al., 1973. Body temperatures in the elderly: a national study of physiological, social, and environmental conditions. British medical journal, 1, pp.200-206. Available at: http://www.pubmedcentral.nih.gov/articlerender.fcgi?artid=1588152\&tool=pmcentrez \&rendertype=abstract.

HMSO, 2011. Energy Act 2011, London, UK: H.M. Government. Available at: http://www.legislation.gov.uk/ukpga/2011/16/contents/enacted/data.htm.

Hong, S. et al., 2009. A field study of thermal comfort in low-income dwellings in England before and after energy efficient refurbishment. Building and Environment, 44(6), pp.1228-1236. Available at: http://linkinghub.elsevier.com/retrieve/pii/S0360132308002254 [Accessed July 21, 2011].

Hong, S., Oreszczyn, T. \& Ridley, I., 2006. The impact of energy efficient refurbishment on the space heating fuel consumption in English dwellings. Energy and Buildings, 38(10), pp.1171-1181. Available at: http://linkinghub.elsevier.com/retrieve/pii/S0378778806000399 [Accessed September 13, 2011]. 
Hunt, D. \& Gidman, M. 1982. A National Field Survey of House Temperatures. Building and Environment, 17(2), pp.107-124.

Liddell, C., 2008. Estimating the health impacts of Northern Ireland's Warm Home Scheme 2000-2008, Ulster. Available at: http://eprints.ulster.ac.uk/26173/1/FPcostbenefitsonweb.pdf [Accessed July 5, 2013].

Milne, G. \& Boardman, B., 2000. Making cold homes warmer : the effect of energy efficiency improvements in low-income homes. Energy Policy, 28.

Ministry of Housing and Local Government, 1961. Homes for today and tomorrow, Nevrala, D.J. \& Pimbert, S.L., 1981. Living room and bedroom temperatures in homes: recorded values, occupant preference and energy conservation potential. Building Services Engineering Research and Technology, 2(3), pp.109-118.

Oreszczyn, T. et al., 2006. Determinants of winter indoor temperatures in low income households in England. Energy and Buildings, 38(3), pp.245-252. Available at: http://linkinghub.elsevier.com/retrieve/pii/S0378778805000964 [Accessed August 30, 2011].

Oseland, N.A., 1994. A comparison of the predicted and reported thermal sensation vote in homes during winter and summer. Energy and Buildings, 21, pp.45-54.

Oseland, N.A., 1995. Predicted and reported thermal sensation in climate chambers, offices and homes. Energy and Buildings, 23, pp.105-115.

Ranson, R.P., 1988. Guidelines for healthy housing, Geneva, Switzerland.

Shipworth, M. et al., 2010. Central heating thermostat settings and timing: building demographics. Building Research and Information, 38(1), pp.50 - 69. Available at: http://discovery.ucl.ac.uk/136822/1/136822_Shipworth et al 2010 CH thermostat settings and timing - building demographics - Accepted Manuscript.pdf [Accessed July 5, 2013]. 
Summerfield, A. et al., 2007. Milton Keynes Energy Park revisited: Changes in internal temperatures and energy usage. Energy and Buildings, 39(7), pp.783-791. Available at: http://linkinghub.elsevier.com/retrieve/pii/S0378778807000576 [Accessed

September 13, 2011].

Utley, J. \& Shorrock, L.D., 2008. Domestic energy fact file 2008. Energy.

Yohanis, Y.G. \& Mondol, J.D., 2010. Annual variations of temperature in a sample of UK dwellings. Applied Energy, 87(2), pp.681-690. Available at:

http://linkinghub.elsevier.com/retrieve/pii/S0306261909003146 [Accessed June 17, 2011].

\section{Endnotes}

${ }^{1}$ CALEBRE (Consumer Appealing Low Energy technologies for Building REtrofitting is a four-year (20082012) £2 million research project funded by EON and RCUK Energy Programme (www.calebre.org.uk)

${ }^{2}$ Hourly average temperature was calculated by taking an average of hourly temperatures recorded across the entire sample. Maximum hourly temperature indicates the highest temperature recorded at every hour across the entire sample. Similarly, minimum hourly temperature indicates the lowest temperature recorded at every hour across the entire sample.

${ }^{3}$ In Figure 8, the term 'occupied' is used when measurements were taken in the presence of the householder; the term 'occupancy may vary' is used when data were continuously recorded over several or more days, with householders assumed to be coming and going; the term 'occupancy very likely' is used when the data presented is for times of day when householders are most likely to have been present (18:00 - 24:00 hrs for living rooms, 00:00-06:00 hrs for bedrooms). 